\title{
EFFECT OF ACARICIDES ON Calepitrimerus vitis (Nalepa, 1905) (ACARI: ERIOPHYIDAE) AND ON THE PRODUCTION OF VINEYARDS ${ }^{1}$
}

\author{
PAULO RICARDO EBERT SIQUEIRA², MARCOS BOTTON ${ }^{3}$, \\ PAULO RICARDO BAIER SIQUEIRA ${ }^{4}$, GIOVANI SILVEIRA PERES 5 , LUCAS DA LUZ SOARES
}

\begin{abstract}
The southernmost region of the state of Rio Grande do Sul, Brazil, has emerged as one of the major poles for fine grape production (Vitis vinifera) for wine processing. In this region, grapevine rust mite (Calepitrimerus vitis) is one of the major pests for the culture; however, information is lacking about production losses caused by this species and acaricides for its control. In this paper, the acaricide effect of azadarachtin, boron + nitrogen on orange peel oil, sulfur and spirodiclofen on C. vitis on Merlot cultivar commercial grapevine was evaluated and production losses caused by the presence of the mite were estimated. The experiment was conducted during the 2012/2013 and 2013/2014 growing seasons, comparing the infestation levels of $C$. vitis and phytoseiid mites on plants treated with acaricides by the use of sticky traps. The acaricides evaluated caused a significant drop in the population of $C$. vitis, and spirodiclofen was the most effective, followed by sulfur, while boron + nitrogen and azadarachtin were the less effective. The products evaluated did not affect the phytoseiid population present in the experimental area. The grape production in parcels treated with spirodiclofen was significantly greater $\left(7.430 \pm 871 \mathrm{~kg} \cdot \mathrm{ha}^{-1}\right)$ than in the uncontrolled parcel $\left(6.074 \pm 316 \mathrm{~kg} \cdot \mathrm{ha}^{-1}\right)$. Significant differences in the total sourness, $\mathrm{pH}$, sugar percentage, and total sugar content of grapes between treated parcels and control were not observed. The control of $C$. vitis with spirodiclofen and sulfur is effective to reduce losses on yield and will not affect the population of Phytoseiids. The control of $C$. vitis should be carried out at the beginning of infestation with rotation of active ingredients.
\end{abstract}

Termos para indexação: Chemical Control, Acaricides, Vitis vinifera, Grapevine Rust Mite.

\section{EFEITO DE ACARICIDAS SOBRE Calepitrimerus vitis (NALEPA, 1905) (ACARI: ERIOPHYIDAE) E NA PRODUÇÃO DE VIDEIRA}

\begin{abstract}
RESUMO - A região da Campanha, no Estado do Rio Grande do Sul, Brasil, tem emergido como um dos principais polos de produção de uvas finas (Vitis vinifera) para processamento. Na região, o ácaro-da-ferrugemda-videira Calepitrimerus vitis é uma das principais pragas da cultura, porém faltam informações sobre perdas na produção causadas pela espécie e de acaricidas para seu controle. Neste trabalho, foi avaliado o efeito acaricida da azadiractina, de boro + nitrogênio veiculados em óleo de casca de laranja, de enxofre e de espirodiclofeno sobre C. vitis em vinhedo comercial da cultivar Merlot, estimando-se as perdas na produção causadas pela presença do ácaro. O experimento foi conduzido durante os anos agrícolas de 2012/2013 e 2013/2014, comparando-se o nível de infestação de C. vitis e ácaros fitoseídeos nas plantas tratadas com os acaricidas, utilizando-se de armadilhas adesivas. Os acaricidas avaliados promoveram uma redução significativa na população de C. vitis, sendo que o espirodiclofeno foi o mais eficaz, seguido por enxofre, enquanto o boro + nitrogênio e a azadiractina foram pouco eficazes. Os produtos avaliados não afetaram a população de fitoseídeos presentes na área experimental. A produção de uvas nas parcelas tratadas com espirodiclofeno foi significativamente maior $\left(7.430 \pm 871 \mathrm{~kg} \cdot \mathrm{ha}^{-1}\right)$ que na testemunha sem controle $(6.074 \pm$ $\left.316 \mathrm{~kg} \cdot h \mathrm{a}^{-1}\right)$. Não foram observadas diferenças significativas na acidez total, $\mathrm{pH}$, percentual de açúcar e açúcar total da uva entre as parcelas tratadas e a testemunha. O controle de C. vitis com espirodiclofeno e enxofre é eficaz para reduzir perdas de produção e não prejudica a população de fitoseídeos. As pulverizações para controle de $C$. vitis devem ser realizadas no início da infestação e com alternância de acaricidas.
\end{abstract}

Termos para indexação: Controle Químico, Acaricidas, Vitis vinifera, Ácaro-da-ferrugem-da-videira.

'(Trabalho 081-15). Recebido em: 18-03-2015. Aceito para publicação em: 05-10-2015.

${ }^{2}$ Eng. Agr. Dr., Prof. do Curso de Agronomia/URCAMP, Bagé-RS. E-mail: siqagro@uol.com.br

${ }^{3}$ Eng. Agr. Dr. Pesquisador/Embrapa Uva e Vinho, Bento Gonçalves-RS. E-mail: marcos.cnpuv@embrapa.br

${ }^{4}$ Eng. Agr. Mestrando Depto. Tecnologia de Sementes/FAEM/UFPel, Pelotas-RS. E-mail: agrosiqueira@yahoo.com.br

${ }^{5}$ Eng. Agr. Batalha Vinhas \& Vinhos, Candiota, RS. E-mail: giovani.peres@vinhosbatalha.com.br

${ }^{6}$ Acadêmico de Agronomia/URCAMP, Bagé-RS. E-mail: lucas.soares1994@hotmail.com 


\section{INTRODUCTION}

The southernmost region of the state of Rio Grande do Sul has emerged as one of the major poles for fine grape production (Vitis vinifera) for wine processing (MELLO; MACHADO, 2013). In this region, grapevine rust mite Vitis Calepitrimerus (NALEPA, 1905) (Acari: Eriophyidae) has been mentioned as one of the main pests of this culture (KLOCK et al, 2011), which has also been reported in other producing countries (BERNARD et al., 2005; Walton et al., 2007, 2010). The species attacks only leaves (KLOCK et al, 2011; JOHANN; FERLA, 2012), being disseminated in the main grape producing regions of southern Brazil, but remains absent in the production pole of Petrolina / Juazeiro, main region of production of fine table grapes of Brazil (DOMINGOS et al., 2014).

Control of the species has been carried out with the use of acaricides, especially abamectin and sulfur, which are authorized for use in the culture for the management of other mite species (Siqueira et al., 2012a). These acaricides are selective to Neoseiulus californicus (McGregor, 1954) (Acari: Phytoseiidae) (SIQUEIRA, 2012b), which is the main species of predatory mite present in the culture (JOHANN; FERLA, 2012). However, other acaricides should be evaluated in order to provide new management tools for producers in a proactive strategy of resistance management. Moreover, there is little information about production losses caused by $C$. vitis and criteria for decision making according to the economic returns of treatments with acaricides. Moura et al. (2013) studied the mite fauna associated with spontaneous vegetation in vineyards in the municipalities of Caxias do Sul and Santana do Livramento, state of Rio Grande do Sul, and found that mite control is preventively carried out with the application of abamectin and / or sulfur, without monitoring, with no knowledge of the level of damage for the different species. As a result of this practice, economic losses may be occurring in many vineyards due to the absence of $C$. vitis control and / or unnecessary expenses by the use of acaricides without the corresponding economic return of the treatment cost.

In other countries, the control of $C$. vitis has been carried out with the use of sulfur, which has reduced potential for selection of resistant populations and also has effect on Erysiphe necator Schwein, the fungus causing powdery mildew (BERNARD et al., 2005; WALTON et al., 2007), and synthetic acaricides such as spirodiclofen, fenpyroximate and fenazaquim (DUSO et al., 2010).
This study aimed to evaluate acaricides for the control of $C$. vitis and evaluate the production of Vitis vinifera plants in the southernmost region of the state of Rio Grande do Sul.

\section{MATERIAL AND METHODS}

The effect of acaricides and productive response of $V$. vinifera in the control of $C$. vitis was studied in commercial vineyard with five hectares of Merlot cultivar grafted on Paulsen 1103 (31 ${ }^{\circ} 25^{\prime} 34$ 'S, 53'43'10'W' and altitude of $265 \mathrm{~m}$ ), located in Candiota, southernmost region of the state of Rio Grande do Sul. The vineyard selected for the experiment was planted in 2010 and conducted in catch wire with cordon, with spacing of $2.5 \mathrm{~m}$ between rows and $1.50 \mathrm{~m}$ between plants. During the experiment, phytosanitary treatments for disease management and competing plants were performed according to the producer's decision, without spraying with acaricides and sulfur. The experiment was conducted in the 2012/2013 and 2013/2014 growing seasons in the period between August 4, 2012 and August 2, 2014, totaling 31 collections, with the interval between samplings of 3 to 4 weeks (Tables 1 and 2). The site was selected because it is located near commercial vineyards with C. vitis infestation history, and with the producer's commitment not to spray substances with recognized acaricide effect.

The experimental design was a randomized block design with four replications, evaluating the following treatments in their commercial product dosages (p.c.) per 100 liters of water: a) azadirachtin (Azamax $\left.{ }^{\circledR}, 300 \mathrm{~mL}\right)$; b) boron 0.06 $\mathrm{g} / \mathrm{L}+$ nitrogen $0.6 \mathrm{~g} / 1$ diluted in orange peel oil (Orobor N1TM® $50 \mathrm{~mL}$ ); c) sulfur (Kumulus DF® $500 \mathrm{~g}$ ); d) spirodiclofen (Envidor $240 \mathrm{SC}{ }^{\circledR}, 30 \mathrm{ml}$ ); and e) control - water. Each block consisted of 8 rows containing 120 plants, of which the $2^{\text {nd }}, 3^{\text {rd }}$, $6^{\text {th }}$ and $7^{\text {th }}$ received treatment, leaving the others as drift protection. In rows that received treatments, plots were demarcated, consisting of 10 plants between two consecutive gaps, each with five plants, corresponding to 15 meters of row and in two adjacent rows, totaling 20 plants per replicate and 30 meters of rows. Inside the rows, plots were allocated, keeping the gaps untreated to serve as surrounds.

In the first growing season (2012/2013), applications were made on October 4 and November 9, 2012 and January 24, 2013. In the second experimental year, sprays were carried out on October 3 and December 6, 2013 and January 20, 2014. The first spraying of each year was performed 
when the percentage of traps with the presence of mite in control plants approached the recommended level of $20 \%$, with the presence of mite suggested by Siqueira et al. (2011a), which occurred on October 1, 2012 (15.6\% of traps with C. vitis) (Table 3) and September 20, 2013 (C. vitis present in $15.6 \%$ of traps) (Table 4). The other products were sprayed in order to suppress the population peaks of the species, which in the municipality of Candiota have higher intensity between January and mid-March (SIQUEIRA et al, 2011b;. JOHANN; FERLA, 2012).

Applications were made with knapsack sprayer brand Jato with pressure regulator equipment, which was kept constant at $15 \mathrm{lbf} \mathrm{pol}^{-2}$, cone type nozzle model MAG 4 and sufficient spray volume for the full wetting of the plant surface, variable with age and phenological stage of plant development, corresponding from the first to the last spraying (two years of research), to the consumption of $133 ; 200$; $267 ; 364 ; 667$ and 670 liters of syrup per hectare. The monitoring of the $C$. vitis population was conducted using sticky traps (Siqueira et al., 2011b), consisting of colorless double-sided adhesive tape segments (Adelbras ${ }^{\circledR}$ ) with $11 \mathrm{~mm}$ in width installed below the second bud in first branches of production so as to surround these branches, which remained on the plants for about 4 days. In each repetition, 8 plants were sampled, disregarding first and last, regarded as borders, and a trap was collected from each plant. After this period, the tapes were collected, distended and fixed on microscope glass slides $(25 \times 75 \mathrm{~mm})$, in the direction that they were found in the plant, being packed in blade supports, which were taken to the laboratory for evaluation of $C$. vitis population. In the laboratory, the number of $C$. vitis per trap was recorded using a stereomicroscope with $40 \mathrm{x}$ magnification, recording the presence of Phytoseiidae, which were considered in this taxon for being affixed to the blades, making it difficult identification at species level.

The number of $C$. vitis in each collection was divided by the days of permanence in traps in the vineyard; and the means were compared by the Duncan test at $5 \%$ probability. Production in parcels was determined only in the 2013/2014 growing season, harvesting on March 14, 2014 all bunches from six central plants in each row of the experimental unit. Bunches were kept 24 hours in cold room with temperature control at $15^{\circ} \mathrm{C}$. Then, the weight of each parcel was recorded by analyzing the Babo degree, $\mathrm{pH}$, total acidity and total sugar, according to methodology of the Adolfo Lutz Institute (1985).

\section{RESULTS AND DISCUSSION}

\section{First Growing Season - 2012/2013}

The first record of $C$. vitis in sticky traps occurred on August 21, 2012 (Table 1). This collection was considered premature for the month of October observed by Johann and Ferla (2012). The population of $C$. vitis in control plants remained below one mite per day per trap, by the end of November. Although it has not been evaluated, the low population density in control plants was attributed to the ability of young leaf tissues of the vineyard to produce defense proteins in response to the attack of eriophids, causing their mortality, a situation mentioned by Walton et al. (2010). On December 29, 2012, 20 days after the second application of acaricides, increase in the population of $C$. vitis was recorded when plants in control parcels showed, on average, 10.84 mites per trap / day. This level of infestation was significantly higher than that observed in treatments with application of acaricides (Table 1). The same trend was observed in evaluation carried out on January 18, which recorded 141 mites per trap per day, a population increase of 14 times in the control with a 20-day interval. (Table 1). Significant differences recorded between treatments in evaluations carried out on December 29 and on January 18 confirm the effective acaricide action of products sprayed in the initial infestation conditions. The population increase verified in parcels without treatment was due to the new generations, the high temperature in the period (Figure 1), being $26.9^{\circ} \mathrm{C}$ the ideal temperature for the development of $C$. vitis (Walton et al., 2010).

The third application of acaricides in the first growing season occurred on January 24 and on February 6, 2013 in all treatments, except where acaricide spirodiclofen was applied, C. vitis showed population growth compared to the previous sample (Table 1). This time, the highest population peak of the experiment was recorded, with 641 mites per trap / day in plants that did not receive acaricides, while in plants treated with spirodiclofen, only 10 mites per trap / day were recorded. In plants sprayed with sulfur, 268 mites per trap / day were recorded, which was below control, but with no differences among acaricides. Similar results were observed by Siqueira et al. (2012b) with spirodiclofen presenting, in most evaluations, higher decrease in the $C$. vitis population compared to sulfur.

Catches of $C$. vitis in sticky traps during the population peak in plants without acaricides were higher than those observed by Siqueira et al. (2011b), which, in the same municipality and Cabernet 
Sauvignon cultivar with identical methodology, registered in the population peak 29.5 mites per trap in the 2007/2008 growing season, while in the following year (2008/2009), only 0.43 were registered.

This observation shows that $C$. vitis is acclimated to the southernmost region of the state of Rio Grande do Sul and with possibility of presenting high population rates in favorable conditions. Moreover, it appears that control with spirodiclofen reduced mite population in 64 times during the population peak, corroborating the results by Siqueira et al. (2012a). A marked reduction is caused by interference in the development of immature mites, reducing fertility and fecundity of adults, including ovicidal effect, which is verified even under conditions of reduced dosages (VAN POTTELBERGE et al., 2009).

Spraying with sulfur reduced the population of $C$. vitis around $40 \%$, a result that confirms the possibility of reducing the species population with sequential applications at 14 days of interval on average, as reported by Siqueira et al. (2013).

Orobor is a foliar fertilizer based on orange peel oil enriched with boron and nitrogen, which has insecticidal action on immature Lepidoptera such as Anagasta kuehniella Zeller (Lepidoptera: Pyralidae), being selective to parasitoid Trichogramma pretiosum rileyi (Hymenoptera: Trichogrammatidae) and compatible with entomopathogenic Beauveria bassiana (Bals.) Vuillemin and Isoria sp., enabling the use of integrated production systems (Luckmann, 2013). After the first spray of this product, there was no infestation of $C$. vitis in subsequent evaluations on October 19 and November 9, and after the second application, 0.01 mites / trap / day on November 29; 3.03 mites on December 29, and on January 18, 2013, 37.98 mites were found, which are significantly lower than the control (Table 1). Spraying on January 24 was not effective to reduce infestation in the following assessment, on February 6, when the orange oil showed 497 mites / trap / day, not differing from the control, featuring an alternative to control the initial infestation.

At the population peak, mites were captured in $100 \%$ of traps in all treatments (Table 3). The time of population peak coincided with the view of the tanning symptoms on leaves, situation also reported in the United States of America by Walton et al. (2010) and also in Rio Grande do Sul (Siqueira et al., 2011a).

After the population peak, a marked reduction in the number of catches was observed on March 1, 2013, without significant differences between parcels treated with acaricides and control. Similar situations are reported by De Lillo et al. (2004) in Italy and by Siqueira et al. (2011b) in Rio Grande do Sul, who found that, from the end of February, C. vitis starts the displacement of leaves and annual branches for shelter locations in the trunk of plants.

From April 2013, catches of C. vitis were even lower, with the highest record found in plants treated with spirodiclofen, averaging 2 mites per trap / day. These plants showed still green leaves, while, in others, especially those without application of acaricide, leaves were tanned, chlorotic and senescent, which can be attributed to infestation of eriophyidae during the cycle.

\section{Second Growing Season - 2013/2014}

During the winter rest period of vineyards between May and July, catches of C. vitis in sticky traps were recorded. This behavior is considered atypical for the species that usually remains in deutogenous condition in wintry shelters, when there are no shoots for food and posture (Walton et al., 2007).

At the beginning of budding on September 72013 , catches in control plants reached 2.55 mites / trap / day (Table 2), 28 times higher than those recorded on September 4, 2012, when 0.08 mites / trap / day were found (Table 1). Until the first application of acaricide on the second experimental year (October 3, 2013), no significant differences were recorded between treatments, a situation that was repeated until November 8 . In the evaluation performed on December 2, 2013, catches of mites in treatments with acaricides were significantly lower than in control, demonstrating the effect of acaricides on $C$. vitis when applied in October. After the second spraying held on December 6 2013, catches in plants treated with spirodiclofen and sulfur were significantly reduced in the sampling carried out on December 13. On December 26, 2013, the population of $C$. vitis in parcels without acaricide increased by 10 times in the interval of 13 days, while in other treatments, except for sulfur, catches were significantly lower.

In the 2013/2014 harvest season, the population peak of mites on control plants occurred on January 11, 2014, which recorded an average of 173 mites / trap / day, which is numerically similar to that observed on 18 January 2013, with 141 mites / trap / day.

On January 20, 2014, the third spraying was conducted in the second year of evaluation of acaricides aiming to control the population increase 
recorded in the equivalent period in the previous year. However, on January 30, 2014, there was a sharp decline in catches after the population peak in all treatments, including control, which showed no significant difference in parcels treated with acaricides. As observed in the first growing season after the population peak, the presence of $C$. vitis decreased significantly and according to De Lillo et al. (2004) and Siqueira et al. (2011b), this reduction is attributed to the displacement of deutogenous ways to hibernation sites in the trunk. On February 20, the number of $C$. vitis in traps was even more reduced, maintaining this condition until May 28, 2014, when the last catches of $C$. vitis were recorded.

In the second experimental year from evaluation carried out in the early formation of buds on September 7, 2013 up to November 8, the percentage of traps with catches showed no significant differences between control and treatments with acaricide (Table 4). From December 2, both in treatment with spirodiclofen as with azadirachtin, the lowest incidences were recorded (Table 4). Satisfactory results in the control of Tetranychus urticae Koch (Acari: Tetranichidae) were obtained in strawberry crops, with sequential sprayings of azadirachtin, product selective to predatory mite $N$. californicus (Bernardi et al, 2013), predatory species predominant in the vineyards of Rio Grande do South (JOHANN; FERLA, 2012). From the second spraying held on December 6, acaricide spirodiclofen significantly reduced the incidence of mites in the traps in the two samplings that followed application on December 13 and 26, 2013 and January 11, 2014.

The third application of the second experimental year took place on January 20, 2014 and in the following evaluation (January 30 ), the incidence of $C$. vitis in treatment with spirodiclofen was lower than in other treatments. On February 20, there were no significant differences, while on March 14 , the condition of January 30 was repeated, with smaller catches on plants sprayed with acaricide. In the other samplings, from this moment, the incidence level was similar among treatments (Table 4).

Marked variations in infestation of $C$. vitis between two consecutive growing seasons were observed in Brazil in Cabernet Sauvignon (Siqueira et al., 2011b), Chardonnay and Merlot cultivars (Siqueira et al., 2013).

In Spain, Perez Moreno and Moraza Zorrilla (1998) found that the population peak of $C$. vitis was more intense when the average monthly temperature was $24,7^{\circ} \mathrm{C}$, whereas in years whose population peaks were lower, the temperature in the same period oscillated between 21.8 and $23,8^{\circ} \mathrm{C}$. In this study, during the first experimental year, the average temperature prior to the highest peak was $21,86^{\circ} \mathrm{C}$ and in the second year, it was $26.11^{\circ} \mathrm{C}$ (Figure 1), no longer showing the same correspondence between temperature and population peaks observed in that country.

In the two evaluation years, it was observed that acaricide spirodiclofen was the treatment that in the highest number of evaluations showed lower infestations compared to control (five times in both years), followed by sulfur (three times in both years) boron + nitrogen (twice in the first year and three times in the second) and azadirachtin (twice in each year) (Tables 1 and 2).

The results demonstrated that $C$. vitis can be efficiently controlled with synthetic acaricides such as spirodiclofen, as well as the use of sulfur, corroborating the results by Lillo et al. (2004) and Bernard et al. (2005). In this case, it is noteworthy that spirodiclofen does not yet have any record for grape culture in Brazil (AGROFIT, 2015), while sulfur can be used to control the species in conventional and organic production systems.

In the second experimental year, treatment with boron + nitrogen presented in general infestations similar to treatment with spirodiclofen (Table 2), and during the population peak on January 11, 2014, infestation was equivalent to $47 \%$ of control. This performance demonstrates the possibility of using this product in sequential sprays or alternating with other acaricides or even in the first mite infestations.

Azadirachtin provided at population peaks in both evaluation years, reduction of about $30 \%$ in the population of C. vitis. According to Bernardi et al. (2013), population reductions above $70 \%$ were reported in T. urticae on strawberry crops with sequential applications at 7-day intervals. Azadirachtin has biological activity period of approximately 72 hours and after this period, the effect of temperature and photodegradation reduce contamination risks in food and make the product more selective to natural enemies (SCHLESENER et al. 2013). In this study, the shortest interval between applications was 36 days, which could justify the lower effect observed with the application of this acaricide.

\section{Occurrence of predatory mites}

The percentage of traps with presence of predatory mites of the Phytoseiid family showed no significant differences among treatments, and the first catches of these mites occurred on February 6, 2013, coinciding with the time of most pronounced population peak of $C$. vitis. From this date, there 
was reduction in the number of phytoseiid catches, although with constant record of occurrence in all sampling times until July 31, 2013, considered the end of the first growing season (Table 3).

Similarly to the first experimental year, in the second experimental year, the percentage of traps with presence of predators of the Phytoseiid family showed no significant differences among treatments, and the first captures of these mites occurred on January 11, 2014, in the period of population peak of $C$. vitis (Table 4). There was an increase in the incidence of these predators in traps on January 30,2014 , following a reduction in the number of catches, but with constant presence in all sampling times until the end of the period considered as the second growing season on August 2, 2014 (Table 4).

Studies conducted in vineyards in Rio Grande do Sul by Klock et al. (2011) associated the abundance of phytoseiid to the presence of mite such as $C$. vitis while Moura et al. (2013) attributed the abundance of phytoseiid not to the presence of mite, but to the lower use of acaricides.

Although there are significant and substantial differences among population of C.vitis on various periods (Tables 1 and 2), and also in relation to the incidence of this mite, in no opportunity, the presence of phytoseiidae showed significant differences (Tables 3 and 4). Similar situation was observed in Australia, where leaves with symptoms and 3.070 C. vitis per leaf showed, on average, 5.8 phytoseiidae, while asymptomatic leaves contained 594 mites and 4.6 phytoseiid, with significant differences for the phytophagous species, but not for the predator (SCHREINER et al., 2014).

In control plants and in both evaluation years, it was observed that the emergence of phytoseiid predators occurred concomitantly with the population peak of C. vitis and in evaluation following the population peak of Phytoseiidae, there was a sharp reduction in the phytophagous mite population. In these plants, the increasing presence of phytoseiid was observbed from the first (34\%) to the second (50\%) experimental year (Tables 2 and 4) and also the occurrence in June and August 2014 (Figure 1), the period of vegetative rest of vineyard.

Based on the observations of this study, although phytoseiid species have not been identified, the authors emphasize the low correlation of mites of this family with the population of $C$. vitis. Despite this finding, it is noteworthy that phytoseiid species are considered the main $C$. vitis antagonists, and the adoption of strategies that allow the conservation of these predators, such as the maintenance of natural vegetation within the vineyard and the use of selective treatment should be prioritized (DUSO et al., 2010). In the case of selectivity, Siqueira et al. (2012b) found that azadirachtin, sulfur and spirodiclofen are harmless to $N$. californicus adults, one of the main predators of phytophagous species in grape cultures (KLOCK et al, 2011; MOURA et al, 2013.).

\section{Effects of $C$. vitis control on production}

The productivity of Merlot cultivar without acaricide treatment was $6.074 \pm 316 \mathrm{~kg} \mathrm{ha}^{-1}$, significantly lower than $7.430 \pm 871 \mathrm{~kg} \mathrm{ha}^{-1}$ obtained in parcels sprayed with spirodiclofen, which did not differ in productivity $\left(7.052 \pm 340 \mathrm{~kg} \cdot \mathrm{ha}^{-1}\right)$ obtained in treatment with sulfur (Table 5). The decrease in production observed in plants without $C$. vitis control (control) was 22 and $16 \%$ compared to those treated with spirodiclofen and sulfur, respectively. The levels of reduction in the production of grapes are comparable to $24 \%$ registered in the United States of America (Walton et al., 2007), being mainly attributed to the effect of phytophagous on the photosynthetic activity. Schreiner et al. (2014) found that grape leaves with symptoms of $C$. vitis attack showed photosynthesis levels $44 \%$ lower than asymptomatic leaves.

The qualitative parameters of grapes (Table 5) showed no significant differences among the different treatments, demonstrating that $C$. vitis negatively interfered in vineyard productivity, but not on the qualitative parameters analyzed. Rizzon and Miele (2009) evaluated 34 Merlot wines produced in the Serra Gaucha region and found intermediate levels of volatile acidity, suggesting better care for the grape and during winemaking to reduce acidity. In this study, treatment with spirodiclofen, sulfur and boron + nitrogen showed production increases, while the total acidity of grapes in these treatments did not vary significantly, with a slight downward trend in comparison to control, which is a characteristic favorable for the production of fine wines (Table 5).

Grapes in the most productive treatment (spirodiclofen) showed total sugar content of $191.34 \mathrm{~g} . \mathrm{L}^{-1}, 4.04 \%$ lower than in the control (199.08g.L-1) (Table 5), which corroborates the results obtained by Brighenti et al. (2010), who evaluated the effect of pruning on the quality of Merlot cultivar grapes and concluded that plants with larger leaf area produced fruits with low sugar levels. In this study, damage caused by $C$. vitis to control contributed to the lower photosynthesis rate of leaves, reducing production, but increasing the concentration of total sugars. 
TABLE 1 - Number of daily catches of Calepitrimerus vitis per trap in the 2012/2013 growing season. Candiota-RS, 2014.

\begin{tabular}{|c|c|c|c|c|c|}
\hline \multirow[t]{2}{*}{$\begin{array}{c}\text { Collection } \\
\text { period }\end{array}$} & \multicolumn{5}{|c|}{ Treatment } \\
\hline & Control & $\begin{array}{l}\text { Azadirachtin } \\
3.6 \mathrm{~g} .100 \mathrm{~L}^{-1}\end{array}$ & $\begin{array}{c}\text { Boron }+ \\
\text { Nitrogen } 0.06+ \\
0.6 \text { g. } 100 \mathrm{~L}^{-1}\end{array}$ & $\begin{array}{c}\text { Sulfur } \\
\text { 400g.100L }\end{array}$ & $\begin{array}{c}\text { Spirodiclofen } \\
7,2 \mathrm{~g} \cdot 100 \mathrm{~L}^{-1}\end{array}$ \\
\hline $07-08-12$ & $0.00 \pm 0.00^{1}$ n.s. & $0.00 \pm 0.00$ & $0.00 \pm 0.00$ & $0.00 \pm 0.00$ & $0.00 \pm 0.00$ \\
\hline $21-08-12$ & $0.01 \pm 0.01 \mathrm{n} . \mathrm{s}$. & $0.00 \pm 0.00$ & $0.01 \pm 0.01$ & $0.00 \pm 0.00$ & $0.00 \pm 0.00$ \\
\hline 04-09-12 & $0.08 \pm 0.0$ n.s. & $0.05 \pm 0.02$ & $0.17 \pm 0.11$ & $0.06 \pm 0.02$ & $0.13 \pm 0.05$ \\
\hline $20-09-12$ & $0.60 \pm 0.28 \mathrm{a}$ & $0.04 \pm 0.01 b$ & $0.03 \pm 0.01 b$ & $0.09 \pm 0.03 b$ & $0.05 \pm 0.02 \mathrm{~b}$ \\
\hline 04-10-12 & $0.51 \pm 0.24 \mathrm{n} . \mathrm{s}$ & $0.34 \pm 0.24$ & $0.12 \pm 0.07$ & $0.13 \pm 0.07$ & $0.16 \pm 0.07$ \\
\hline $19-10-12$ & $0.01 \pm 0.01$ n.s. & $0.06 \pm 0.03$ & $0.00 \pm 0.00$ & $0.15 \pm 0.09$ & $0.03 \pm 0.01$ \\
\hline $09-11-12$ & $0.00 \pm 0.00$ n.s. & $0.01 \pm 0.00$ & $0.00 \pm 0.00$ & $0.00 \pm 0.00$ & $0.02 \pm 0.01$ \\
\hline $29-11-12$ & $0.03 \pm 0.01 \mathrm{n} . \mathrm{s}$ & $0.02 \pm 0.01$ & $0.01 \pm 0.00$ & $0.03 \pm 0.01$ & $0.01 \pm 0.00$ \\
\hline $29-12-12$ & $10.84 \pm 2.26 \mathrm{a}$ & $4.07 \pm 0.66 \mathrm{bc}$ & $3.03 \pm 0.84 \mathrm{~cd}$ & $5.46 \pm 1.33 b$ & $1.29 \pm 0.49 \mathrm{~d}$ \\
\hline $18-01-13$ & $141.66 \pm 18.93 \mathrm{a}$ & $75.47 \pm 19.84 b$ & $37.98 \pm 5.45 b$ & $56.02 \pm 9.02 b$ & $24.24 \pm 3.62 b$ \\
\hline $06-02-13$ & $641.21 \pm 68.16 \mathrm{a} 4$ & $458.61 \pm 62.03 \mathrm{ab}$ & $497.35 \pm 79.32 \mathrm{ab}$ & $268.61 \pm 25.75 b c$ & $10.92 \pm 1.98 \mathrm{c}$ \\
\hline $1-03-13$ & $15.56 \pm 4.03 \mathrm{ab}$ & $21.23 \pm 9.71 \mathrm{ab}$ & $7.82 \pm 2.40 \mathrm{ab}$ & $37.14 \pm 7.93 \mathrm{a}$ & $1.67 \pm 0.48 b$ \\
\hline 09-04-13 & $1.58 \pm 0.31$ n.s. & $2.53 \pm 0.43$ & $1.32 \pm 0.28$ & $1.82 \pm 0.33$ & $2.00 \pm 0.44$ \\
\hline $18-05-13$ & $0.05 \pm 0.02 \mathrm{a}$ & $0.01 \pm 0.01 \mathrm{ab}$ & $0.04 \pm 0.02 \mathrm{ab}$ & $0.04 \pm 0.01 \mathrm{ab}$ & $0.00 \pm 0.00 \mathrm{~b}$ \\
\hline $29-06-13$ & $0.02 \pm 0.0 \mathrm{n} . \mathrm{s}$ & $0.01 \pm 0.00$ & $0.01 \pm 0.00$ & $0.01 \pm 0.00$ & $0.04 \pm 0.03$ \\
\hline $31-07-13$ & $0.17 \pm 0.06 \mathrm{a}$ & $0.09 \pm 0.06 \mathrm{ab}$ & $0.02 \pm 0.02 \mathrm{ab}$ & $0.03 \pm 0.01 \mathrm{ab}$ & $0.00 \pm 0.00 \mathrm{~b}$ \\
\hline
\end{tabular}

Mean $( \pm \mathrm{SE})$ followed by different letters in the line differ by the Duncan test $(\mathrm{p} \leq 0.05) .{ }^{1}=$ Number of $C$. vitis individuals per trap per day. n.s. $=$ Differences are not statistically significant.

TABLE 2 - Number of daily catches of Calepitrimerus vitis per trap in the 2013/2014 growing season. Candiota-RS, 2014.

\begin{tabular}{cccccc}
$\begin{array}{c}\text { Collection } \\
\text { period }\end{array}$ & \multicolumn{5}{c}{$\begin{array}{c}\text { Treatment } \\
\text { Boron }+\end{array}$} \\
& Control & $\begin{array}{c}\text { Azadirachtin } \\
\text { 3.6g. } 100 \mathrm{~L}^{-1}\end{array}$ & $\begin{array}{c}\text { Nitrogen } 0.06+ \\
0.6 \mathrm{~g} .100 \mathrm{~L}^{-1}\end{array}$ & $\begin{array}{c}\text { Sulfur } \\
400 \mathrm{~g} .100 \mathrm{~L}^{-1}\end{array}$ & $\begin{array}{c}\text { Spirodiclofen } \\
7,2 \mathrm{~g} .100 \mathrm{~L}^{-1}\end{array}$ \\
\hline $07-09-13$ & $2.55 \pm 0.63^{1}$ n.s. & $2.24 \pm 0.58$ & $1.49 \pm 0.41$ & $1.82 \pm 0.44$ & $0.72 \pm 0.36$ \\
$1-10-13$ & $0.18 \pm 0.07$ n.s. & $0.14 \pm 0.06$ & $0.12 \pm 0.05$ & $0.14 \pm 0.05$ & $0.14 \pm 0.08$ \\
$08-11-13$ & $0.04 \pm 0.03$ n.s. & $0.00 \pm 0.00$ & $0.02 \pm 0.01$ & $0.10 \pm 0.07$ & $0.01 \pm 0.01$ \\
$02-12-13$ & $5.17 \pm 1.19 \mathrm{a}$ & $0.48 \pm 0.16 \mathrm{~b}$ & $1.73 \pm 0.57 \mathrm{~b}$ & $1.54 \pm 0.34 \mathrm{~b}$ & $0.46 \pm 0.18 \mathrm{~b}$ \\
$13-12-13$ & $13.09 \pm 1.55 \mathrm{a}$ & $5.98 \pm 1.70 \mathrm{ab}$ & $5.32 \pm 1.27 \mathrm{ab}$ & $3.44 \pm 0.75 \mathrm{~b}$ & $0.38 \pm 0.10 \mathrm{~b}$ \\
$26-12-13$ & $137.34 \pm 14.52 \mathrm{a}$ & $58.94 \pm 7.14 \mathrm{bc}$ & $64.53 \pm 8.48 \mathrm{bc}$ & $84.64 \pm 14.46 \mathrm{ab}$ & $1.06 \pm 0.21 \mathrm{c}$ \\
$11-01-14$ & $173.75 \pm 35.39 \mathrm{a}$ & $119.10 \pm 17.55 \mathrm{ab}$ & $82.25 \pm 11.94 \mathrm{ab}$ & $160.97 \pm 33.60 \mathrm{a}$ & $9.31 \pm 1.30 \mathrm{~b}$ \\
$30-01-14$ & $6.02 \pm 0.71 \mathrm{ab}$ & $6.41 \pm 0.73 \mathrm{ab}$ & $7.12 \pm 1.16 \mathrm{ab}$ & $15.31 \pm 3.11 \mathrm{a}$ & $1.97 \pm 0.60 \mathrm{~b}$ \\
$20-02-14$ & $0.75 \pm 0.17$ n.s. & $0.69 \pm 0.17$ & $0.94 \pm 0.32$ & $0.88 \pm 0.18$ & $0.47 \pm 0.13$ \\
$14-03-14$ & $1.55 \pm 0.38 \mathrm{ab}$ & $2.00 \pm 0.34 \mathrm{ab}$ & $2.76 \pm 0.49 \mathrm{a}$ & $2.26 \pm 0.44 \mathrm{ab}$ & $0.54 \pm 0.26 \mathrm{~b}$ \\
$10-04-14$ & $0.03 \pm 0.02 \mathrm{~b}$ & $0.13 \pm 0.07 \mathrm{ab}$ & $0.06 \pm 0.04 \mathrm{ab}$ & $0.16 \pm 0.06 \mathrm{a}$ & $0.16 \pm 0.07 \mathrm{a}$ \\
$02-05-14$ & $0.03 \pm 0.03$ n.s. & $0.00 \pm 0.00$ & $0.00 \pm 0.00$ & $0.00 \pm 0.00$ & $0.16 \pm 0.07$ \\
$28-05-14$ & $0.00 \pm 0.00 \mathrm{n} . \mathrm{s}$. & $0.00 \pm 0.00$ & $0.07 \pm 0.07$ & $0.00 \pm 0.00$ & $0.00 \pm 0.00$ \\
$24-06-14$ & $0.00 \pm 0.00$ & $0.00 \pm 0.00$ & $0.00 \pm 0.00$ & $0.00 \pm 0.00$ & $0.00 \pm 0.00$ \\
$02-08-14$ & $0.00 \pm 0.00$ & $0.00 \pm 0.00$ & $0.00 \pm 0.00$ & $0.00 \pm 0.00$ & $0.00 \pm 0.00$
\end{tabular}

Mean $( \pm \mathrm{SE})$ followed by different letters in the line differ by the Duncan test $(\mathrm{p} \leq 0.05) .{ }^{1}=$ Number of $C$. vitis individuals per trap per day. n.s. $=$ Differences are not statistically significant. 
TABLE 3- Percentage of traps with incidence of Calepitrimerus vitis $(\mathrm{Cv})$ and Phytoseiidae $(\mathrm{Ph})$ in the 2012/2013 growing season. Candiota-RS, 2014.

\begin{tabular}{|c|c|c|c|c|c|c|c|c|c|c|}
\hline \multirow{3}{*}{$\begin{array}{c}\text { Collection } \\
\text { period }\end{array}$} & \multicolumn{10}{|c|}{ Treatment } \\
\hline & \multicolumn{2}{|c|}{ Control } & \multicolumn{2}{|c|}{$\begin{array}{c}\text { Azadirachtin } \\
3.6 \mathrm{~g} .100 \mathrm{~L}^{-1}\end{array}$} & \multicolumn{2}{|c|}{$\begin{array}{c}\text { Boron }+ \\
\text { Nitrogen } 0.06+ \\
0.6 \mathrm{~g} .100 \mathrm{~L}^{-1}\end{array}$} & \multicolumn{2}{|c|}{$\begin{array}{c}\text { Sulfur } \\
400 \mathrm{~g} .100 \mathrm{~L}^{-1}\end{array}$} & \multicolumn{2}{|c|}{$\begin{array}{c}\text { Spirodiclofen } \\
7,2 \mathrm{~g} \cdot 100 \mathrm{~L}^{-1}\end{array}$} \\
\hline & $C v^{1}$ & $\mathrm{Ph}^{2}$ & $C v$ & $\mathrm{Ph}$ & $C v$ & $\mathrm{Ph}$ & $C v$ & $\mathrm{Ph}$ & $C v$ & $\mathrm{Ph}$ \\
\hline $07-08-12$ & 0.0 n.s. & 0.0 n.s. & 0.0 & 0.0 & 0.0 & 0.0 & 0.0 & 0.0 & 0.0 & 0,0 \\
\hline $21-08-12$ & 3.1n.s. & 0.0 n.s. & 0.0 & 3.1 & 3.1 & 0.0 & 0.0 & 0.0 & 0.0 & 0,0 \\
\hline 04-09-12 & 25.0 n.s. & 0.0 n.s. & 15.6 & 0.0 & 21.9 & 0.0 & 18.8 & 0.0 & 25.0 & 0,0 \\
\hline $20-09-12$ & 15.6 n.s. & 0.0 n.s. & 18.8 & 0.0 & 15.6 & 0.0 & 28.1 & 0.0 & 18.8 & 0,0 \\
\hline 04-10-12 & 25.0 n.s. & 0.0 n.s. & 25.0 & 0.0 & 21.9 & 0.0 & 21.9 & 0.0 & 28.1 & 0,0 \\
\hline $19-10-12$ & 3.1 n.s. & 0.0 n.s. & 12.5 & 0.0 & 0.0 & 0.0 & 12.5 & 0.0 & 9.4 & 0,0 \\
\hline $09-11-12$ & 0.0 n.s. & 0.0 n.s. & 3.1 & 0.0 & 0.0 & 0.0 & 0.0 & 0.0 & 3.1 & 0,0 \\
\hline 29-11-12 & 12.5 n.s. & 0.0 n.s. & 6.2 & 0.0 & 3.1 & 0.0 & 9.4 & 0.0 & 3.1 & 0,0 \\
\hline $29-12-12$ & 87.5 n.s. & 0.0 n.s. & 93.8 & 0.0 & 65.6 & 0.0 & 87.5 & 0.0 & 65.6 & 0,0 \\
\hline $18-01-13$ & 100 n.s. & 0.0 n.s. & 100 & 0.0 & 100 & 0.0 & 100 & 0.0 & 96.9 & 0,0 \\
\hline $06-02-13$ & 100n.s. & 18.8 n.s. & 100 & 3.1 & 100 & 18.8 & 100 & 15.6 & 100 & 15,6 \\
\hline $1-03-13$ & $93.8 \mathrm{a}$ & 34.4 n.s. & $93.8 \mathrm{a}$ & 31.2 & $87.5 \mathrm{a}$ & 25.0 & $90.6 \mathrm{a}$ & 40.6 & $59.4 b$ & 18,8 \\
\hline 09-04-13 & 84.4n.s. & 12.5 n.s. & 84.4 & 9.4 & 62.5 & 9.4 & 87.5 & 12.5 & 59.4 & 15,6 \\
\hline $18-05-13$ & $25.0 \mathrm{a}$ & 0.0 n.s. & $6.2 \mathrm{ab}$ & 3.1 & $12.5 \mathrm{ab}$ & 3.1 & $21.9 \mathrm{a}$ & 6.2 & $0.0 \mathrm{~b}$ & 3,1 \\
\hline $29-06-13$ & 12.5n.s. & 0.0 n.s. & 3.1 & 3.1 & 3.1 & 3.1 & 3.1 & 0.0 & 6.2 & 0,0 \\
\hline $31-07-13$ & 12.5n.s. & 0.0 n.s. & 12.5 & 6.2 & 3.1 & 6.2 & 9.4 & 6.2 & 0.0 & 3,1 \\
\hline
\end{tabular}

Means followed by different letters in the line differ by the Duncan test $(\mathrm{p} \leq 0.05) .{ }^{1}=$ Percentage of traps with incidence of $C$. vitis. ${ }^{2}$

$=$ Percentage of traps with incidence of Phytoseiidae. n.s. $=$ Differences are not statistically significant.

TABLE 4- Percentage of traps with incidence of Calepitrimerus vitis $(\mathrm{Cv})$ and Phytoseiidae $(\mathrm{Ph})$ in the 013/2014 growing season. Candiota-RS, 2014.

\begin{tabular}{|c|c|c|c|c|c|c|c|c|c|c|}
\hline \multirow[t]{2}{*}{$\begin{array}{l}\text { Collection } \\
\text { period }\end{array}$} & \multicolumn{2}{|c|}{ Control } & \multicolumn{2}{|c|}{$\begin{array}{c}\text { Azadirachtin } \\
3.6 \mathrm{~g} .100 \mathrm{~L}^{-1}\end{array}$} & $\begin{array}{r}\text { Tre } \\
\text { Bor } \\
\text { Nitrog } \\
0.6 \mathrm{~g}\end{array}$ & $\begin{array}{l}\text { ment } \\
1+ \\
0.06+ \\
0 L^{-1}\end{array}$ & \multicolumn{2}{|c|}{$\begin{array}{c}\text { Sulfur } \\
\text { 400g.100L } \mathrm{L}^{-1}\end{array}$} & \multicolumn{2}{|c|}{$\begin{array}{l}\text { Spirodiclofen } \\
7,2 \mathrm{~g} \cdot 100 \mathrm{~L}^{-1}\end{array}$} \\
\hline & $C v^{1}$ & $\mathrm{Ph}^{2}$ & $C v$ & $\mathrm{Ph}$ & $C v$ & $\mathrm{Ph}$ & $C v$ & $\mathrm{Ph}$ & $C v$ & $\mathrm{Ph}$ \\
\hline $07-09-13$ & $87.5 \mathrm{ab}$ & $0.0 \mathrm{n} . \mathrm{s}$ & $96.9 \mathrm{a}$ & 0.0 & $59.9 \mathrm{~b}$ & 0.0 & $75.0 \mathrm{ab}$ & 0.0 & $28.1 \mathrm{~b}$ & 0,0 \\
\hline $1-10-13$ & 15.6 n.s. & 0.0 n.s. & 18.8 & 0.0 & 15.6 & 0.0 & 18.8 & 0.2 & 12.5 & 0,0 \\
\hline $08-11-13$ & $6.2 \mathrm{ab}$ & 0.0 n.s. & $0.0 \mathrm{~b}$ & 0.0 & $3.1 \mathrm{~b}$ & 0.0 & $15.6 \mathrm{a}$ & 0.0 & $3.1 \mathrm{~b}$ & 0,0 \\
\hline $02-12-13$ & $87.5 \mathrm{a}$ & 0.0 n.s. & $37.5 \mathrm{~b}$ & 0.0 & $43.8 \mathrm{ab}$ & 0.0 & $68.8 \mathrm{ab}$ & 0.0 & $31.2 \mathrm{~b}$ & 0,0 \\
\hline $13-12-13$ & $96.9 \mathrm{a}$ & 0.0 n.s. & $93.8 \mathrm{a}$ & 0.0 & $87.5 \mathrm{a}$ & 0.0 & $81.2 \mathrm{a}$ & 0.0 & $50.0 \mathrm{~b}$ & 0,0 \\
\hline $26-12-13$ & $100 \mathrm{a}$ & 0.0 n.s. & $100 \mathrm{a}$ & 0.0 & $100 \mathrm{a}$ & 0.0 & $100 \mathrm{a}$ & 0.0 & $59.4 \mathrm{~b}$ & 0,0 \\
\hline $11-01-14$ & $100 \mathrm{a}$ & 3.1 n.s. & $100 \mathrm{a}$ & 0.0 & $100 \mathrm{a}$ & 0.0 & $100 \mathrm{a}$ & 0.0 & $93.8 b$ & 0,0 \\
\hline $30-01-14$ & $100 \mathrm{a}$ & 50.0 n.s. & $100 \mathrm{a}$ & 40.6 & $100 \mathrm{a}$ & 46.9 & $100 \mathrm{a}$ & 43.8 & $93.8 b$ & 46,9 \\
\hline $20-02-14$ & 40.6n.s & 6.2 n.s. & 34.4 & 0.0 & 53.1 & 6.2 & 53.1 & 0.0 & 31.2 & 0,0 \\
\hline $14-03-14$ & $71.9 \mathrm{a}$ & 18.8 n.s. & $78.1 \mathrm{a}$ & 31.2 & $90.6 \mathrm{a}$ & 21.9 & $84.4 \mathrm{a}$ & 15.6 & $40.6 \mathrm{~b}$ & 18,8 \\
\hline $10-04-14$ & $6.2 \mathrm{n} . \mathrm{s}$ & 6.2 n.s. & 12.5 & 6.2 & 6.2 & 0.0 & 15.6 & 3.1 & 12.5 & 6,2 \\
\hline $02-05-14$ & 0.0 & 0.0 n.s. & 0.0 & 9.4 & 0.0 & 3.1 & 0.0 & 6.2 & 3.1 & 3,1 \\
\hline $28-05-14$ & 0.0 & 0.0 n.s. & 0.0 & 0.0 & 3.1 & 3.1 & 0.0 & 0.0 & 3.1 & 0,0 \\
\hline $24-06-14$ & 0.0 & 3.1 n.s. & 0.0 & 0.0 & 0.0 & 0.0 & 0.0 & 6.2 & 0.0 & 6,2 \\
\hline $02-08-14$ & 0.0 & 3.1 n.s. & 0.0 & 0.0 & 0.0 & 6.2 & 0.0 & 0.0 & 0.0 & 0,0 \\
\hline
\end{tabular}

Means followed by different letters in the line differ by the Duncan test $(\mathrm{p} \leq 0.05) .{ }^{1}=$ Percentage of traps with incidence of $C$. vitis. ${ }^{2}$ $=$ Percentage of traps with incidence of Phytoseiidae. n.s. $=$ Differences are not statistically significant. 
TABLE 5- Productivity, increase in production and qualitative parameters of Merlot cultivar submitted to different acaricides. Candiota-RS, 2014.

\begin{tabular}{|c|c|c|c|c|c|c|}
\hline Treatment & $\begin{array}{l}\text { Productivity } \\
\left(\mathrm{kg}^{-h^{-1}}\right)^{-1}\end{array}$ & $\begin{array}{l}\text { Increase in } \\
\text { relation to control }\end{array}$ & Graus Babo & $\mathrm{pH}$ & $\begin{array}{l}\text { Total acidity } \\
\left(\text { g. } . L^{-1}\right)\end{array}$ & $\begin{array}{r}\text { Açúcar } \\
\left(\mathrm{g} . \mathrm{L}^{-1}\right)\end{array}$ \\
\hline $\begin{array}{l}\text { Spirodiclofen } \\
7.2 \mathrm{~g} .100 \mathrm{~L}^{-1}\end{array}$ & $7.430 \pm 871 \mathrm{a}$ & $22.32 \%$ & 19.6 n.s. & 3.21 n.s. & $6.08 \mathrm{n} . \mathrm{s}$ & 191.34 n.s. \\
\hline Sulfur $400 \mathrm{~g} \cdot 100 \mathrm{~L}^{-1}$ & $7.052 \pm 340 \mathrm{ab}$ & $16.10 \%$ & 19.0 & 3.22 & 5.92 & 197.10 \\
\hline $\begin{array}{c}\text { Boron }+ \text { Nitrogen } 0,06 \\
+0,6 \mathrm{~g} \cdot 100 \mathrm{~L}^{-1}\end{array}$ & $6.228 \pm 376 b c$ & $2.54 \%$ & 19.4 & 3.12 & 5.70 & 195.40 \\
\hline Control 3,6g.100L $\mathrm{L}^{-1}$ & $6.074 \pm 316 b c$ & -- & 19.4 & 3.24 & 6.22 & 199.08 \\
\hline Azadirachtin & $5.778 \pm 608 \mathrm{c}$ & $(4.87) \%$ & 18.6 & 3.23 & 6.38 & 197.22 \\
\hline
\end{tabular}

Mean $( \pm$ SE) followed by different letters in the column differ by the Duncan test $(p \leq 0.05)$. n.s. $=$ differences are not statistically significant.

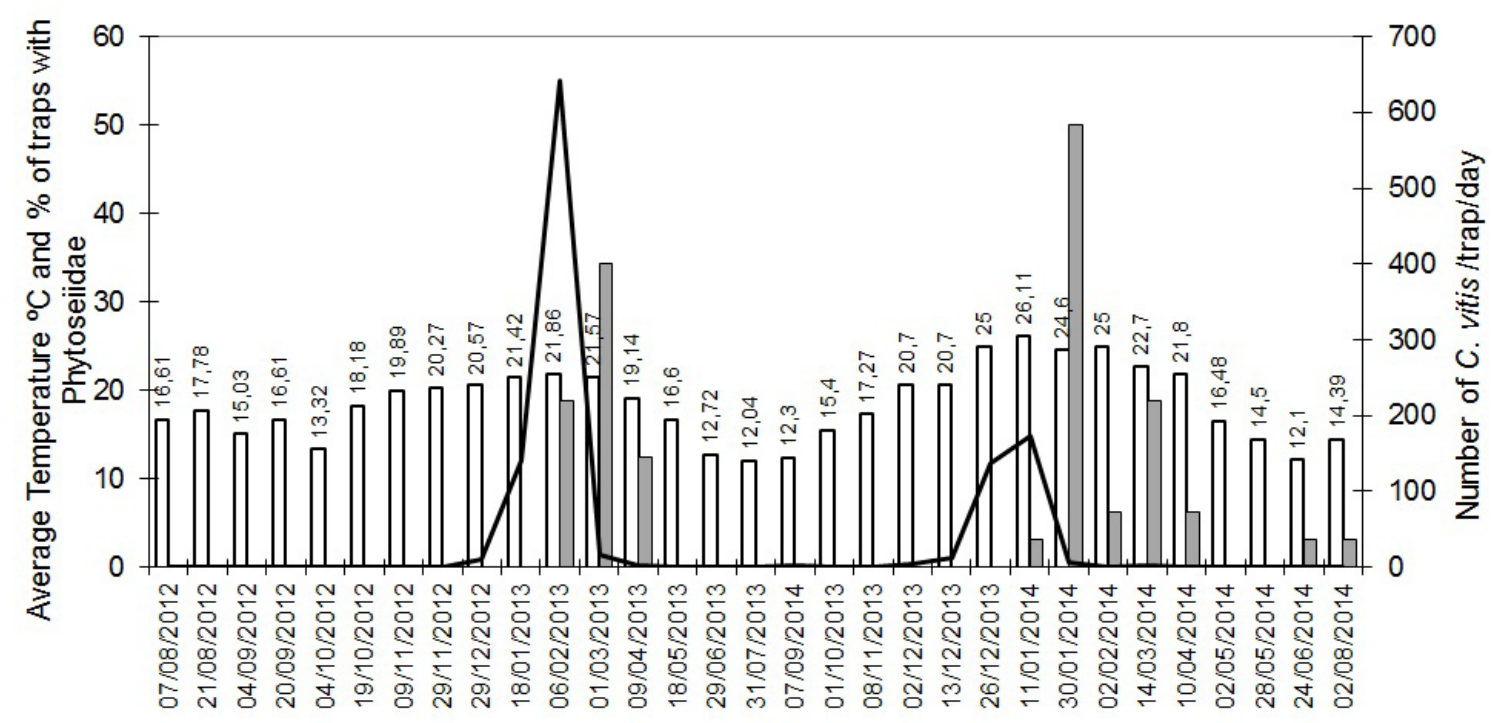

Datas de coleta

$\square$ Average temperaure daily $\square$ Incidence of Phytoseiidae $\longrightarrow$ C.vitis (mite/trap/day)

FIGURE 1- Population fluctuation of Calepitrimerus vitis, incidence of phytoseiid in traps and thermal variation in the 2012/2013 and 2013/2014 seasons. Candiota-RS, 2014. 


\section{CONCLUSIONS}

Spirodiclofen and sulfur control C. vitis in vineyards.

Spraying must be carried out in the early mite infestation and using alternated acaricides.

C. vitis attack reduces the production of Merlot cultivar plants by $22 \%$.

The control of $C$. vitis does not interfere in the total sugar content, percentage of sugars, $\mathrm{pH}$ and total acidity in Merlot cultivar plants.

\section{REFERENCES}

AGROFIT Sistema de Agrotóxicos Fitossanitário. Ministério da Agricultura Pecuária e Abastecimento. 2015. Disponível em: $<$ http://agrofit.agricultura.gov. br/agrofit cons/principal agrofit cons $>$. Acesso em: 07 jan. 2015.

BERNARD, M.B.; HORNE, P.A.; HOFFMANN, A.A. Eriophyoid mite damage in Vitis vinifera (grapevine) in Australia: Calepitrimerus vitis and Colomerus vitis (Acari: Eriophyidae) as the common cause of de widespread 'Restricted Spring Growth' syndrome. Experimental and Applied Acaralogy, Amsterdam, v.35, n.1, p.83-109, 2005.

BERNARDI, D.; BOTTON, M.; da CUNHA, U.S.; BERNARDI, O.; MALAUSA, T.; GARCIA, M.S.; NAVA, D.E. Effects of azadirachtin on Tetranychus urticae (Acari: Tetranychidae) and its compatibility with predatory mites (Acari: Phytoseiidae) on strawberry. Pest Management Science, Hoboken, v.69, n.1, p.75-80, 2013.

BRIGHENTI, A.F.; RUFATO, L.; KRETZSCHMAR, A.A.; MADEIRA, F.C. Desponte dos ramos de videira e seu efeito na qualidade dos frutos de 'Merlot' sobre os porta-enxertos 'Paulsen 1103' e 'Couderc 3309'. Revista Brasileira de Fruticultura, Jaboticabal, v.32, n.1, p.19-26, 2010.

DE LILLO, E.; MONFREDA, R.; BALDACCHINO, F. Efficacy of fungicides and acaricides against Calepitrimerus vitis (Nalepa). Phytophaga, Calcutta, v.14, p.599-603, 2004
DOMINGOS, C.A.; MELO, J.W.S.; OLIVEIRA, J.E.M.; GONDIM JR. Mites on grapevines in northeast Brazil: occurrence, population dynamics, and within-plant distribution. International Journal of Acarology, London, v.4, n.2, p.145-151, 2014.

DUSO, C.; CASTAGNOLI, M.; SIMONI, S.; ANGELI, G. The impact the eriophyoids on crops: recent issues on Aculus schlechtendali, Calepitrimerus vitis and Aculops lycopersici. Experimental and Applied Acarology, Amsterdam, v.51, p.151-168. 2010.

INSTITUTO ADOLFO LUTZ. Normas analíticas do Instituto Adolfo Lutz: métodos químicos e físicos para análise de alimentos. 3. ed. São Paulo, 1985 , v. 1, 533p.

JOHANN, L.; FERLA, N.J. Mite (Acari) population dynamics in grapevines (Vitis vinifera) in two regions of Rio Grande do Sul, Brazil. International Journal of Acarology, Oak Park, v.38, p.1-8, 2012.

KLOCK, C.L; JOHANN, L.; BOTTON, M.; FERLA, N.J. Mitefauna (Arachinida:Acari) associated to grapevine, Vitis vinifera L. (Vitaceae), in the municipalities of Bento Gonçalves and Candiota, Rio Grande do Sul, Brasil. Check List, Viçosa, v.7, n.4, p.522-536, 2011.

LUCKMANN, D. Compatibilidade de produtos naturais comerciais a fungos entomopatogênicos e seletividade a Trichogramma pretiosum (Hymenoptera: Trichogrammatidae). 2013. 88f. Dissertação (Mestrado: Produção Vegetal) Universidade Federal Tecnológica do Paraná, Pato Branco, 2013.

MELLO, L.M.R; MACHADO, C.A.E. Área cultivada com videiras no Rio Grande do Sul. Bento Gonçalves: Embrapa Uva e Vinho, 2013.49p. (Documentos, 87).

MOURA, R.B.; BERTOLO, F.O.A.; OTT, A.P. Acarofauna associada à vegetação espontânea de vinhedos. Ciência Rural, Santa Maria, v.43, n.9, p.1610-1617, 2013. 
PÉREZ MORENO, I.P.; MORAZA ZORRILLA, M.L. Population dynamics and hibernation shelters of Calepitrimerus vitis in the vineyards of Rioja, Spain, with a description of a new eriophyid extraction technique (Acari: Eriophyidae). Experimental and Applied Acarology, Amsterdam, v.22, p.215-226, 1998.

RIZZON, L.A; MIELE, A. Características analíticas de vinho Merlot da Serra Gaúcha. Ciência Rural, Santa Maria, v.39, n.6, p.1913-1916, 2009.

SCHLESENER, D.C.H.; DUARTE, A.F.; GUERRERO, M.F.C.; CUNHA, U.S.; NAVA, D.E. Efeitos do Nim sobre Tetranychus urticae Koch (Acari: Tetranychidae) e os predadores Phytoseiulus macropilis (Banks) e Neoseiulus californicus (McGregor) (Acari: Phytoseidae). Revista Brasileira de Fruticultura, Jaboticabal, v.35, n.1, p.59-66, 2013.

SCHREINER, R.P.; SKINKIS, P.A.; DREVES, A.J. A rapid method to asses grape rust mite on leaves and observations from case studies in western Oregon vineyards. Hort Technology, Oregon, v.24, n.1, p.38-47, 2014.

SIQUEIRA, P.R.E.; BOTTON, M.; FERLA, N.J.; JOHANN, L.; FORMEHL, G.; GRÜTZMACHER, A.D.; HÄRTER, W. Acarinose da videira no Rio Grande do Sul. Bento Gonçalves: Embrapa Uva e Vinho, 2011a. 8p. (Circular Técnica, 85).

SIQUEIRA, P.R.E.; GRÜTZMACHER, A.D.; BOTTON, M.; KOHN, R.A.G. Flutuação populacional do ácaro-da-ferrugem-da-videira em vinhedo comercial em Candiota, RS, com diferentes métodos de amostragem. Ciência Rural, Santa Maria, v.41, n.9, p.1489-1495, 2011 b.

SIQUEIRA, P.R.E.; GRÜTZMACHER, A.D.; CUNHA, U.S.; KOHN, R.G.; KOHN, E.T. Efeito de agrotóxicos sobre Calepitrimerus vitis (Nalepa, 1905) (Acari: Eriophyidae) na Região da Campanha do Rio Grande do Sul. Revista Brasileira de Fruticultura, Jaboticabal, v.34, n.1, p.84-92, 2012a.
SIQUEIRA, P.R.E; BOTTON, M.; FERLA, N.J.; GRÜTZMACHER, A.D.; JOHANN, L.; SIQUEIRA, P.R.B. Toxicidade residual de agrotóxicos sobre adultos de Neoseiulus californicus (Mc Gregor) (Acari: Phytoseiidae) na cultura da videira. Revista Científica Rural, Bagé, v.14, n.1, p.31-45, 2012 b.

SIQUEIRA, P.R.E; BOTTON, M.; KOHN, R.G.; GRÜTZMACHER, A.D.; PERES, G.S. Dinâmica populacional de Calepitrimerus vitis (Nalepa) (Acari: Eriophyidae) em cultivares de videira Região da Campanha do Rio Grande do Sul. Revista Brasileira de Fruticultura, Jaboticabal, v.35, n.2, p.446-453, 2013.

VAN POTTELBERGE, S.; KHAJEHALI, J.; VAN LEEUWEN, T.; TIRRY, L. Effects os spirodiclofen on reproduction in a susceptible and resistant strain of Tetranychus urticae (Acari: Tetranychidae). Experimental and Applied Acarology, Amsterdam, v.47, p.301-309, 2009.

WALTON, V.M.; DREVES, A.J.; COOP, L.B.; JONES, G.V.; SKINKIS, P.A. Developmental parameters and seasonal phenology of Calepitrimerus vitis (Acari: Eriophyidae) in vine grapes of Western Oregon. Environmental Entomology, College Park, v.39, n.6, p.2008-2016, 2010.

WALTON, V.M.; DREVES, A.J.; GENT, D.H.; JAMES, D.G.; MARTIN, R.R.; CHAMBERS, U.; SKINKIS, P.A. Relationship between rust mites Calepitrimerus vitis (Nalepa), bud mites Colomerus vitis (Pagenstecher) (Acari: Eriophyidae) and short shoot syndrome in Oregon vineyards. International Journal Acarology, Abingdon, v.33, n.4, p.307-318, 2007. 